\title{
РАЧУНАРСКИ ПОДРЖАНО ПРОЈЕКТОВАЊЕ ПУТЕВА СА ПРИМЕРОМ ПРИМЕНЕ ПРОГРАМСКОГ ПАКЕТА СЕСS 2.0
}

\section{COMPUTER-AIDED DESIGN OF ROADS WITH EXAMPLE OF APPLICATION OF SOFTWARE CECS 2.0}

\author{
Милош Краљ, Факултет техничких наука, Нови Сад
}

\section{Област- ГРАЂЕВИНАРСТВО}

Кратак садржај - У раду су приказане могућности програмског пакета CECS 2.0 - Civil Engineering CAD Solution, са примером примене на пројекту појачаног одржавања (рехабилитације) државног пута IБ 35 , на деоници Кладово - Брза Паланка, од стационаже $\mathrm{km} \mathrm{25+400.00} \mathrm{до} \mathrm{km} \mathrm{27+500.00} \mathrm{у} \mathrm{укупној} \mathrm{дужини} \mathrm{од}$ $L=2,1 \mathrm{~km}$. Анализирани су постојећи елементи пута (ситуащиони план, подужни профил и попречни профили). На основу израчунатог укупног еквивалентног саобраћајног оптерећења у пројектном периоду, за меродавну саобраћајну траку и геомеханичких карактеристика терена, димензионисана је коловозна конструкиија на предметној деоници. Применом програмског пакета CECS 2.0 израђен је пројекат појачаног одржавања предметне деониче.

Кључне речи: Пројектовање путева, CAD, CECS 2.0, појачано одржавање.

\begin{abstract}
This paper presents possibilities of the software CECS 2.0 - Civil Engineering CAD Solution, with an example of application of this software in preparation of the Design for Heavy Maintenance of the State Road IB Class, No. 35 on the road section Kladovo - Brza Palan-

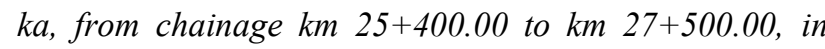
total lenght of $L=2.1 \mathrm{~km}$. The existing road elements (layout, longitudinal profile and cross-sections) were analyzed. Pavement structure is dimensioned on the basis of calculated total equivalent traffic load during the project period, for the relevant traffic lane and geomechanical characteristics of terrain. Design for heavy maintenance of the subject road section was prepared with application of the software CECS 2.0.
\end{abstract}

Key words: Road design, CAD, CECS 2.0, heavy maintenance.

\section{1. УВОД}

У раду су описане могућности примене програмског пакета CECS 2.0 при пројектовању путева и изради пројекта појачаног одржавања ванградске деонице пута у дужини од $L=2,1 \mathrm{~km}$.

\section{НАПОМЕНА:}

Овај рад је проистекао из мастер рада чији је ментор био др Небојша Радовић, в.проф.
Помоћу програмског пакета CECS 2.0, анализирано је стање постојећих хоризонталних и вертикалних елемената трасе, а потом је у домену могућности пројекта појачаног одржавања, које искључује експропријацију земљишта ван путног појаса, у максималној могућој мери поправљено постојеће стање геометрије пута и прилагођено савременим прописима за рачунску брзину од $\mathrm{Vr}=80 \mathrm{~km} / \mathrm{h}$. Помоћу програмског пакета CECS 2.0 су пројектовани и обележени елементи ситуационог плана, нивелационог плана, подужног профиа и попречних профила.

\section{2. МОГУЋНОСТИ ПРИМЕНЕ ПРОГРАМСКОГ ПАКЕТА CECS 2.0}

Програмски пакет CECS, је настао 2006 године, са основном наменом за анализу и пројектовање путева и железница. Као своју основу може да користи програм AutoCAD, BricsCAD ili ZWCAD+. Применом програмског пакета CECS 2.0, кориснику се пружа могућност да:

- формира и уреди дигитални модел терена;

- пројектује и обележи ситуациони план;

- формира, пројектује и обележи подужни профил;

- формира, пројектује и обележи попречне профиле;

- изврши обрачун количина радова са попречних профила;

- формира и обележи нивелациони план и план обележавања;

- табеларно прикаже списак елемената за исклочавање трасе;

- да формира 3D моделе линијских и површинских елемената и објеката и моделује косине;

- изврши проверу стабилности потпорних зидова...

На услузи кориснику су бројне геодетске алатке као и многе помоћне команде. Програмски пакет CECS 2.0 је нарочито погодан за пројектовање пројеката рехабилитације путева, јер омогућава приказивање постојеће шеме витоперења на подужном профилу и приказивање граничне вредности (минималне висине) нивелете на подужном профилу у зависности од задате висине надградње (или подградње) на попречним профилима и опционо, постојеће или пројектоване шеме витоперења. Поред тога могуће је динамички повезати подужни и попречне профиле што много убрзава процес анализе и пројектовања нивелете. 


\section{3. АНАЛИЗА ПОСТОЈЕһЕГ СТАҢА}

\section{1 Циљ спровођења анализе}

Циљ спровођења анализе постојећег стања је утврђивање стања коловоза, затим геометрије пута и величине елемената, којима се описује постојеће стање пута (елементи попречног профила пута, хоризонтална и вертикална геометрија трасе), као и стања и геометрије раскрсница, прикључака и додатних саобраћајних површина дуж трасе.

\section{2 Поступак израде анализе постојећег стања}

Анализа постојећег стања представља почетну активност у изради техничке документације. У првом кораку извршена је анализа постојећег стања коловозне конструкције и геометрије пута, на основу доступне архивске документације, непосредно прикупљених података на терену и апроксимацијом постојећих елемената геометрије пута, снимљеног на геодетској подлози.

Овим поступком, прикупљени су следећи параметри којима је описано постојеће стање пута:

- подаци о саобраћајном оптерећењу;

- геомеханичке карактеристике терена;

- подаци о врсти застора на државном путу и његовом стању;

- подаци о коловозној конструкцији државног пута;

- геометријске карактеристике државног пута;

- геометријске карактеристике раскрсница; прикључака и аутобуских стајалишта.

\section{3 Опис постојећег стања коловозне конструкције}

Анализом постојеће архивске документације о изведеним истражним радовима, утврђено је да је састав коловозне конструкције следећи:

- хабајући слој - АБ11 д=3cm;

- битуменизирани шљунак д=6cm;

- дробљени камени материјал д=41cm

На предметној деоници уочена су следећа оштећења:

- алигатор мрежасте пукотине уз ивицу коловоза са благим улегнућем;

- попречне пукотине;

- мрежасте блок пукотине и

- испливавање битумена.

Уз обе ивице коловоза се налазе бетонске ивичне траке које су у лошем стању, а геометрија банкина је генерално у добром стању.

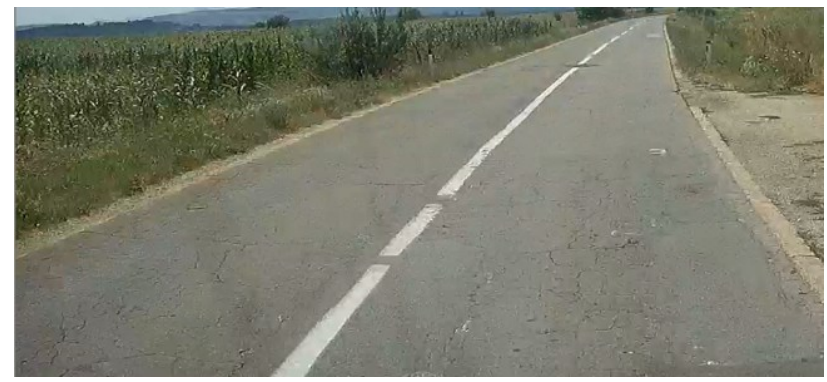

Слика 1: Карактеристична оштећења коловоза на деоници

\section{4 Опис постојећег стања геометрије пута}

Коловоз се на већем делу предметне деонице налази на ниском насипу, а само локално на високом насипу или у усеку. Ширина коловоза износи око 6m, а за $\mathrm{Vr}=80 \mathrm{~km} / \mathrm{h}$, прописана је ширина од $7.2 \mathrm{~m}$.

На деоници постоји укупно 9 кривина, од којих је једна са најмањим, а уједно и најмањим прописаним радијусом за рачунску брзину од $\mathrm{Vr}=80 \mathrm{~km} / \mathrm{h}$, који износи $250 \mathrm{~m}$. Хоризонтална кривина са највећим радијусом на деоници је радијуса $1250 \mathrm{~m}$. Само једна кривина према постојећем стању има прелазнице, а према пропису, готово све би требале да их имају. Попречни нагиби коловоза у кривинама су мањи од прописаних вредности за рачунску брзину $\mathrm{Vr}=80 \mathrm{~km} / \mathrm{h}$.

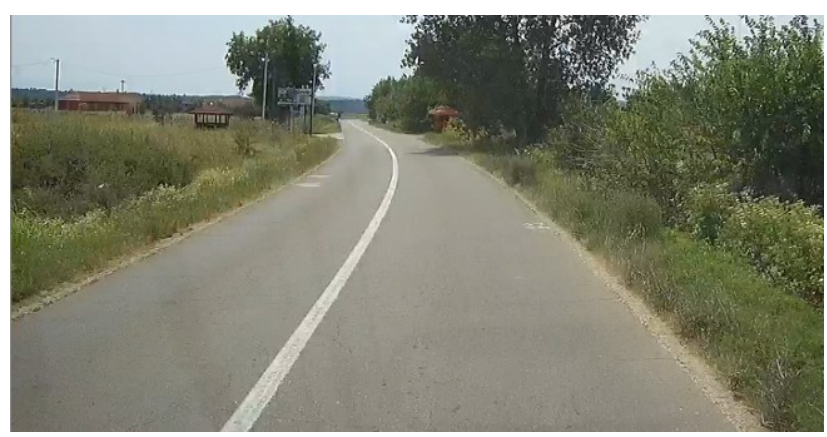

Слика 2: Државни пут IB35

Према постојећем стању, уколико се занемаре блаже деформације нивелете, нивелета пута мења подужни нагиб на 3 локације. Подужни нагиби нивелете су у опсегу од минималних $0.04 \%$ до максималних $0.77 \%$, што је у складу са прописима. На једној од поменуте три локације где се нивелета ломи, не постоји вертикално заобљење, што је прихватљиво, јер је разлика нагиба на прелому нивелете мала. На остале две локације постоје вертикалне кривине великих радијуса, конвексна кривина радијуса око 19250m и конкавна кривина радијуса око $25000 \mathrm{~m}$, што је у складу са прописима.

Дуж предметне деонице државног пута постоји укупно 9 прикључака, од чега се 4 налази у склопу две раскрснице, а осталих 5 прикључака су некатегорисани путеви. На деоници постоји једно аутобуско стајалиште које нема свог пара са друге стране пута.

\section{4. ТЕХНИЧКО РЕШЕЊЕ}

Техничким решењем је предвиђена рехабилитација коловоза са пројектним периодом од 20 година. Геометријски елементи пута су овим пројектним решењем у максимално могућој мери усклађени са прописаним вредностима за брзину од $\mathrm{Vr}=80 \mathrm{~km} / \mathrm{h}$.

Прописани минимални елементи рачунску брзину од $\mathrm{Vr}=80 \mathrm{~km} / \mathrm{h}$ cy:

- Минимални радијус кривине Rmin=250m

- Минимална вредност параметра прелазних кривина $\mathrm{A}=125$

- Вредност радијуса кривине изнад којег није обавезна примена прелазних кривина $\mathrm{R}=1500 \mathrm{~m}$ (1000m) 
- Дужина међуправца код супротно усмерених кривина $160 \leq \mathrm{L}(\mathrm{m}) \leq 1600$

- Дужина међуправца код истосмерних кривина 320 $\leq \mathrm{L}(\mathrm{m}) \leq 1600$

- Минимални попречни нагиб Ipmin=2,5\%

- Максимални попречни нагиб Ipmax=7\% (8\%)

\section{1 Решење коловозне конструкције}

С обзиром на недовољну ширину коловоза и на лоше стање ивичних трака и слегање коловоза уз ивице коловоза, пројектовано је проширење коловоза, односно парцијална реконструкцја. Уз ивице коловоза предвиђено је рушење ивичних трака и коловозне конструкције у ширини од $0.75 \mathrm{~m}$, те израда нове коловозне консрукције, док је у средини коловоза, пројектовано појачање коловозне конструкције асфалтним слојевима. Пројектована коловозна конструкција уз ивице коловоза и на аутобуским стајалиштима је следећа:

- асфалт бетон - АБ11с

- бит. носећи слој БНС 22сA д $=4 \mathrm{~cm}$;

- бит. носећи слој БНС 22сA

д $=6 \mathrm{~cm}$; д $=6 \mathrm{~cm}$;

- дробљени камени агрегат 0/31.5mm д=20cm;

- дробљени камени агрегат $0 / 63 \mathrm{~mm} \quad$ д=25cm;

- постељица од локалног материјала или насипа од глине;

- сепарациони геотекстил на контакту локалног тла и ДКА 0/63mm.

Пројектована коловозна конструкција на средини коловоза је следећа:0

- асфалт бетон - АБ11с

- бит. носећи слој БНС 22cA д=6cm;

- бит. носећи слој БНС 22cА (по потреби) д=6cm;

- постојећа коловозна конструкција.

На средини коловоза други битуменизирани носећи слој се уводи по потреби, уколико је због пројектоване нивелете и шеме витоперења то потребно. На постојећој коловозној конструкцији су предвиђени припремни радови, односно стругање асфалта, чишћење и прскање битуменском емулзијом.

\section{2 Елементи попречног профила}

Ширина пројектованих елемената попречног профила пута су следеће:

- Ширина саобраћајних трака

$2 \times 3,25 \mathrm{~m}$

- Ширина ивичних трака

$2 \times 0,35$

- Ширина стабилизованих банкина

$2 \mathrm{x} 1,50 \mathrm{~m}$

- Ригол (где је потребно)

$0,75 \mathrm{~m}$

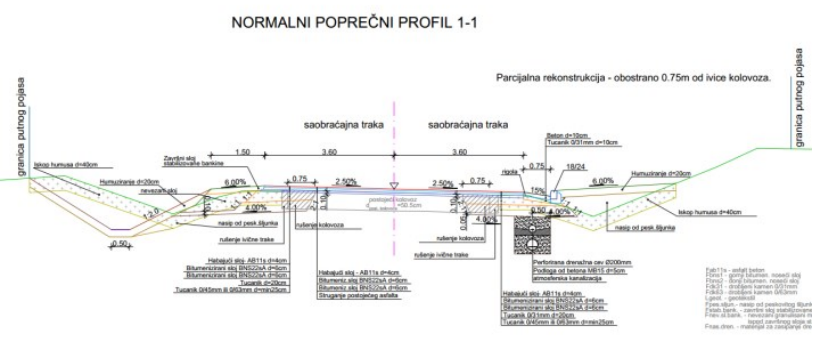

Слика 3: Нормални попречни профил
Попречни нагиби коловоза износе од 2,5\% до 7\%, а попречни нагиб банкина 6\%. Нагиби косина и канала износе $1: 2$. Канали су трапезног облика, а ширина дна канала износи $0,5 \mathrm{~m}$. На појединим локацијама, примењени су бетонски префабриковани канали или риголе. Дубина и ширина дна префабрикованог бетонског канала износи $0,5 \mathrm{~m}$, а косине су нагиба 1:1. Попречни нагиб ригола износи $15 \%$, а берме $6 \%$, са падом ка риголи. Укупна ширина риголе и берме је већа од прописане минималне ширине $(1,25 \mathrm{~m})$.

На деоници су пројектована два аутобуска стајалишта, по једно за сваки смер. Ширина пројектованих аутобуских ниша износи $3,6 \mathrm{~m}$, а попречни нагиб одговара нагибу државног пута уз нишу. Ивичњак уз нишу је димензија $18 / 24 \mathrm{~cm}$, са надвишењем од $+12 \mathrm{~cm}$.

Уз аутобуске нише су пројектоване пешачке стазе, које повезују аутобуска стајалишта оближњом радном зоном. Ширина пројектованих стаза износи $1,5 \mathrm{~m}$, чиме је обезбеђен саобраћајни профил за два пешака. У ширину пешачких стаза улазе и ивичњаци димензија $12 / 18 \mathrm{~cm}$, изузев када се стаза налази одмах уз колвоз, где је ивичњак који дели две саобраћајне површине, додатна површина. Попречни нагиб пешачких стаза је $2 \%$.

\section{3 Ситуационо решење}

На деоници постоји укупно 9 хоризонталних кривина. 4 кривине, на две локације формраију $\mathrm{S}$ кривину, a осталих 5 кривина су кружне.

Табела 1: Списак хоризонталних елемената и попречних нагиба коловоза у кривинама

\begin{tabular}{|c|c|c|c|c|c|c|}
\hline Рб. & $\begin{array}{c}\text { Стационажа } \\
\text { центра } \\
\text { кривине (Km) }\end{array}$ & $\begin{array}{l}\text { Радијус } \\
\text { кривине } \\
\text { (m) }\end{array}$ & Прелазнице & \begin{tabular}{|c|} 
Дужина \\
међуправца \\
(m) \\
\end{tabular} & $\begin{array}{c}\text { Тип } \\
\text { кривине }\end{array}$ & $\begin{array}{c}\text { Попречни } \\
\text { нагиб } \\
(\%) \\
\end{array}$ \\
\hline \multirow{2}{*}{1} & \multirow{2}{*}{$25+577,02$} & \multirow{2}{*}{440} & 175 & 307,13 & \multirow{4}{*}{$\begin{array}{c}S \\
\text { кривина }\end{array}$} & \multirow{2}{*}{5,00} \\
\hline & & & 197 & \multirow{2}{*}{0,00} & & \\
\hline \multirow{2}{*}{2} & \multirow{2}{*}{$25+785,84$} & \multirow{2}{*}{525} & 197 & & & \multirow{2}{*}{4,50} \\
\hline & & & 100 & \multirow{2}{*}{55,10} & & \\
\hline \multirow{2}{*}{3} & \multirow{2}{*}{$25+960,56$} & \multirow{2}{*}{1000} & 0 & & \multirow{2}{*}{$\begin{array}{c}\text { Кружна } \\
\text { кривина }\end{array}$} & \multirow{2}{*}{3,00} \\
\hline & & & 0 & \multirow{2}{*}{2,64} & & \\
\hline \multirow{2}{*}{4} & \multirow{2}{*}{$26+097,28$} & \multirow{2}{*}{450} & 150 & & \multirow{4}{*}{$\begin{array}{c}\text { S } \\
\text { кривина }\end{array}$} & \multirow{2}{*}{5,00} \\
\hline & & & 182 & \multirow{2}{*}{0,00} & & \\
\hline \multirow{2}{*}{5} & \multirow{2}{*}{$26+321,34$} & \multirow{2}{*}{415} & 182 & & & \multirow{2}{*}{5,00} \\
\hline & & & 187 & \multirow{2}{*}{30,59} & & \\
\hline \multirow{2}{*}{6} & \multirow{2}{*}{$26+528,03$} & \multirow{2}{*}{1500} & 0 & & \multirow{2}{*}{$\begin{array}{r}\text { Кружна } \\
\text { кривина }\end{array}$} & \multirow{2}{*}{2,50} \\
\hline & & & 0 & \multirow{2}{*}{94,26} & & \\
\hline \multirow{2}{*}{7} & \multirow{2}{*}{$26+809,58$} & 310 & 155 & & Кружна & 600 \\
\hline & & & 155 & & кривина & \\
\hline 8 & $27+280,80$ & 255 & 125 & 210,51 & Кружна & 7,00 \\
\hline & & 20 & 125 & & кривина & I, \\
\hline & & & 155 & 56,56 & & 3,00 \\
\hline 9 & $27+526,22$ & 450 & & & $\begin{array}{c}\text { Кружна } \\
\text { кривина }\end{array}$ & $\begin{array}{l}\text { (уклапање } \\
\text { у пост. } \\
\text { стање) }\end{array}$ \\
\hline
\end{tabular}

Пројектовани радијуси кривина и попречни нагиби су прописаних вредности за $\mathrm{Vr}=80 \mathrm{~km} / \mathrm{h}$. На свим кривинама на којим је било неопходно, пројектоване су прелазнице одговарајућих вредности, изузев код кривине број 2, где то није било могуће. Ипак одабраним прелазним елементом и код ове кривине, задовољен је естетски и конструктивни критеријум. 


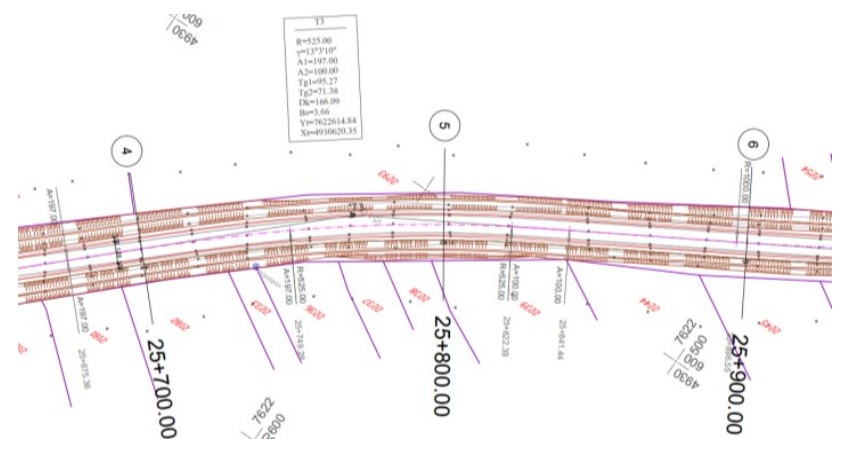

Слика 4: Хоризонтална кривина број 2

Геометрија прикључака у склопу две раскрснице, у великој мери прати постојеће стање, ширина коловоза је на 3 прикључка $5 \mathrm{~m}$, а на четвртом, најпрометнијем, око $9 \mathrm{~m}$. У зони раскрснице на стационажи км 27+140 пројектовано је проширење коловоза, тако да су формиране додатне траке. У смеру раста стационаже су пројектоване траке за лево и десно скретање, док је у супротном смеру пројектована трака за лево скретање (најпрометнији прикључак), а укинута је трака за десно скретање.

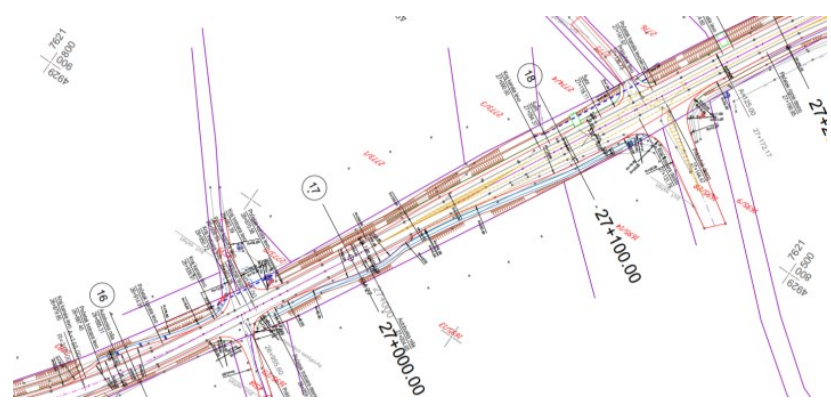

Слика 5: Прикључщуи у склопу раскрсницуа

Ширина трака за лево скретање је $3,00 \mathrm{~m}$, а за десно скретање $3,25 \mathrm{~m}$. Лепезе прикључака су, где год је било простора, пројектоване као троцентричне криве, са средишњим радијусима 7-11m.

На прикључцима некатегорисаних путева, геометрија коловоза је условљена путним појасом тих путева. Ширина коловоза на прикључцима износи 2,75-3,00m, а примењене лепезе на уклапању са државним путем су радијуса 5-7m. Угао прикључења некатегорисаног пута на државни пут је у максималној мери исправљен, па је то уједно и најзначајнија ствар коју је било могуће унапредити у границама путног појаса.

На деоници су пројектована 2 аутобуска стајалишта, на стационажама км 26+892 и км 27+003. Нише су типске, стандарних димензија, ширине $3,6 \mathrm{~m}$ и дужине око $53 \mathrm{~m}$

Уз аутобуска стајалишта, пројектоване су пешачке стазе, које повезују аутобуска стајалишта са оближњом радном зоном. Ширина стаза износи $1.5 \mathrm{~m}$, а укупна дужина око $255 \mathrm{~m}$.

\section{4 Подужни профил}

Нивелету коловоза карактеришу мале вредности подужних нагиба и мали број прелома нивелете. Нагиб нивелете коловоза износи 0.05-0.88\%. Примењени радијуси вертикалних кривина су 20.000$36.000 \mathrm{~m}$. Витоперење је извршено око осовине коловоза, са краком од $3,6 \mathrm{~m}$, а примењени нагиби рампе витоперења су у опсегу $0,2-1,0 \%$.

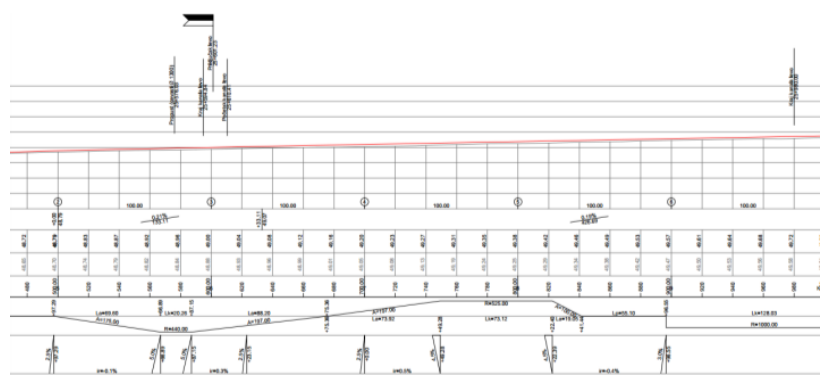

Слика 6: Део подужног профила

\section{5 Одводњавање}

Систем за одводњавање је решен на различите начине, у зависности од услова на локацији. Примењени елементи система за одводњавање су земљани канали, бетонски префабриковани канали, риголи и затворени канализациони систем са сливницима. На већем делу трасе је пројектован вођен систем, а на мањем самоупијајући канали. Канали су вођени до постојећих пропуста и реципијената. На целој деоници, предвиђено је одводњавање постељице

\section{5. ЗАКљУЧАК}

Потреба за рехабилитацијом путева постаје све већа самом изградњом путне мреже и растом друмског саобраћаја. Развој софтвера за пројектовање путева је вишеструко убрзао и поједноставио процес анализе и пројектовања путева, али ипак увек треба бити опрезан приликом њихове употребе, јер у пројектовању путева нумерички тачно решење, не значи увек и добро решење.

\section{6. ЛИТЕРАТУРА}

[1] Правилник о условима које са аспекта безбедности саобраћаја морају да испуњавају путни објекти и други елементи јавног пута (Сл. гласник РС број $50 / 11)$

[2] Скрипта са предавањима из предмета: „Одабрана поглавња из пројектовања путева“ Доц. др Небојша Радовић, дипл.инж.грађ. Факултет техничких наука, Универзитета у Новом Саду, Трг Доситеја Обрадовића 6, 21000 Нови Сад, школске 2012/2013 године.

[3] CECS 2.0 Manual, CAD Solutions, Неде Спасојевић 1/17, 11070 Нови Београд, 2011 године

\section{Кратка биографија:}

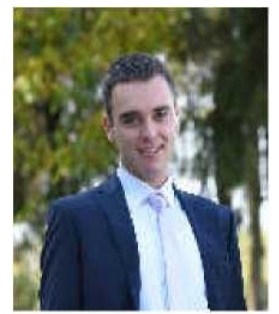

Милош Краљ рођен је у Новом Саду 1992.год. Октобра 2011. године уписује Основне студије на Факултету техничких наука из области Грађевинарства. Децембра 2015. године стиче звање дипломираног грађевинског инжењера на одсеку за путеве, железнице и аеродроме. Мастер рад на Факултету техничкух наука из области путева одбранио је у марту 2019. год. 